\title{
The 'subcortical dementia' of progressive supranuclear palsy
}

\author{
MARTIN L. ALBERT ${ }^{1}$, ROBERT G. FELDMAN, AND ANNE L. WILLIS \\ From the Department of Neurology, University Hospital, Boston University Medical Center \\ and the Neurology Service, Aphasia Research Unit, Boston Veterans Administration Hospital, \\ Boston, Mass., U.S.A.
}

SYNOPSIS Progressive supranuclear palsy (Steele et al.) has a characteristic pattern of dementia: (1) forgetfulness, (2) slowing of thought processes, (3) emotional or personality changes (apathy or depression with occasional outbursts of irritability), and (4) impaired ability to manipulate acquired knowledge. In many neurological disease states associated with subcortical pathology a similar pattern of dementia exists. The neurobehavioural changes of progressive supranuclear palsy thus typify a clinical pattern which may be referred to as subcortical dementia. The subcortical dementias have a striking clinical resemblance to the dementia which occurs after bifrontal lobe disease. However, the subcortical dementias can be clearly distinguished clinically from cortical dementias, other than frontal dementias. We propose as a tentative hypothesis that there may be common pathophysiological mechanisms underlying the subcortical dementias-in particular, disturbances of timing and activation. There are immediate practical implications of this hypothesis: drugs which have an effect on subcortical timing and activating mechanisms may be useful in the treatment of subcortical dementias.

Dementia is a term used to describe a constellation of behavioural signs and symptoms of intellectual dysfunction due to widely varying aetiologies and dependent on separate neurophysiological mechanisms. Analyses of the patterns of disordered behaviour in demented patients may lead to an understanding of the underlying pathophysiological processes and may indicate potentially useful forms of treatment for the dementias.

This communication describes the particular pattern of dementia observed in five patients with progressive supranuclear palsy, a disease entity characterized by supranuclear ophthalmoplegia, pseudobulbar palsy, nuchal dystonia, and dementia. The pattern of intellectual deterioration described in this report has many features in common with that of other reported cases ${ }^{2}$. An analysis of our data and of those from the literature suggests that a behaviour pattern

\footnotetext{
1 Present address: Boston Veterans Administration Hospital, Aphasia Research Unit, 150 South Huntington Avenue, Boston, Mass. 02130, U.S.A.
}

typical for the subcortical dementing diseases exists in progressive supranuclear palsy, and that it may be contrasted with that of the cortical dementing diseases.

\section{CASE 1}

C.S. was a 64 year old, right-handed man admitted to the Neurology Service at University Hospital of Boston University Medical Center on 30 April 1969 for evaluation of a progressive neurological disorder manifested by difficulties with gait and speech. He had been active and healthy until two years before this admission when he began to stammer. His speech became progressively less clear; and his gait was characterized by short shuffling steps with difficulty in initiating walking. He had been evaluated by several other neurologists and the diagnosis of 'an atypical form of Parkinson's disease' was made.

2 Alajouanine et al., 1926; Cornil and Kissel, 1929; Chavany et al., 1951; Verhaart, 1958; Brusa, 1961; Steele et al., 1964; Barbeau, 1965; Messert and van Nuis, 1966; Anastasopoulos et al., 1967; David et al., 1968; Ferri et al., 1968; Pollingher, 1968; Behrman et al., 1969; Blumenthal and Miller, 1969; Constantinidis et al., 1970; Newman et al., 1970; Powell, 1970; Scott, 1970; Steele, 1970. 
Treatment with anti-Parkinsonism drugs (not including L-dopa) had been unsuccessful.

General physical examination on admission was normal. Pertinent neurological findings at that time were as follows. Testing of mental status showed a facial expression of continuous smiling with occasional outbursts of crying; a moderate deficit in recent and remote memory; poor calculating ability; poor abstracting ability. No language (aphasic) or agnosic abnormalities were noted. Speech, however, was quite dysarthric, with an element of festination. Cranial nerves were normal except for those controlling conjugate gaze. There was a marked limitation of voluntary conjugate gaze in all directions, with vertical movements in either direction being more impaired than lateral movements. Vestibuloocular reflexes were preserved. Motor examination revealed normal bulk and strength of muscles with no abnormal involuntary movements. Mild to moderate increase in tone, bradykinesia, and cogwheeling were noted. Deep tendon reflexes were hyperactive in all four extremities. Bilateral grasp, snout, and palmomental reflexes were present. Sensory examination was negative. Cerebellar testing revealed a mild degree of truncal ataxia. Gait was festinating, with marked propulsion and retropulsion.

Blood, urine, and cerebrospinal fluid (CSF) studies were normal. Radiographs of the chest and skull were negative. Electroencephalography (EEG), brain scan, and radioactive iodinated serum albumin (RISA) study were all normal. Pneumoencephalography revealed moderate dilatation of the third and lateral ventricles. The tentative diagnosis of progressive supranuclear palsy was made and a therapeutic trial of L-dopa was started. There was no effect from the drug, and therapy was discontinued.

During the next one and a half years C.S. was evaluated by approximately 10 other neurologists in the greater Boston area, all of whom concurred with the diagnosis. His course was one of steady progression of all the neurological signs and symptoms observed on the first admission. Rigidity of all muscle groups, smoothly continuous throughout passive movement, was the major additional observation. C.S. became unable to feed himself, unable to swallow, and dysphonic. A new trial of L-dopa therapy, started in April 1970, showed a definite improvement in mood and alertness. No improvement of the motor abnormalities was noted and C.S. was confined to a wheelchair.

\section{CASE 2}

A.I. was a 74 year old physician who was admitted to the Neurology Service at University Hospital of
Boston University Medical Center on 20 March 1971 with a chief complaint of 'slowing down and difficulty with vision'. For several months before this admission he had noticed 'stiffness' in his extremities, 'difficulty in walking', and a reduction in the blinking frequency of his eyelids.

General physical examination on admission was normal. A review of pertinent neurological findings revealed the following. Other than some slowness in mentation, mental status was normal. Conjugate vertical gaze was severely limited, in both upward and downward directions. The eyes could be moved vertically, however, by means of the doll's head manoeuvre. Function of the cranial nerves was otherwise normal. There was a mild cogwheel rigidity in all extremities. Muscle bulk and strength $\vec{\circ}$ were normal. Deep tendon reflexes were mildly and symmetrically increased throughout. Babinski signs were not present. Sensation was intact. No cerebellar abnormalities were noted.

Blood, urine, and CSF studies were normal. Radiographs of the skull, brain scan, and electro- iv encephalogram were normal. RISA cysternograph $\vec{N}$ showed no abnormalities. The diagnosis of prot gressive supranuclear palsy was made and he wक्ष started on a therapeutic trial with L-dopa.

During the following year there was a temporar (two to three month) lessening of A.I.'s 'stiffness with L-dopa therapy. After initial improvement, the patient's condition returned to that which it had bee before therapy. There was no improvement in his eye movements. A.I.'s wife commented that he was 'having memory problems', and his ability to perform simple calculations was no longer normal. Occasionally he had difficulty in swallowing, he occasionally fell, and his speech became dysarthric.

On 17 May 1972 the following observations were made concerning A.I.'s mental status: 'He has slowness of thought processes; forgetfulness (not a true memory loss, except that it takes him longer than normal to find words and ideas); changes in his personality (outbursts of irritability); diminished ability to manipulate acquired knowledge'. No aphasia, apraxia, or perceptual abnormalities (agnosias) were noted.

CASE 3

A.N. was a 58 year old white, right-handed woman admitted to the Neurology Service at University Hospital of Boston University Medical Center on 20 o April 1971 with a chief complaint of 'difficulty in N walking'. For one year she complained of slowness and slurring of speech; for almost the same amount 
of time she had difficulty in maintaining her balance, falling several times; and for several months she had difficulty in upward gaze.

General physical examination on admission was normal. Neurological examination was as follows. No evidence of dementia was present. There was a moderate dysarthria. Visual acuity was 20/20 in each eye; colour vision was normal. There was a striking impairment of conjugate upward and downward gaze. This could be improved to full range of motion with the doll's head manoeuvre. There was no nystagmus. Strength was good. There were no abnormalities of tone. Deep tendon reflexes were increased, but Babinski signs were not present. Gait was broadbased, with a tendency to stagger.

Blood, urine, and cerebrospinal fluid studies were normal. Radiographs of the skull, brain scan, and pneumoencephalogram were normal. Radioactive iodinated serum albumin study (RISA) showed a normal CSF flow pattern. EEG showed minimal paroxysmal changes. The diagnosis of progressive supranuclear palsy was made.

During the following year a mild to moderate progression in neurological symptomatology was noted. She also started to manifest changes in personality, alternating between periods of indifference and of irritability. Memory loss became apparent; and she was readmitted in May 1972 for evaluation of her dementia.

Medical and neurological examinations were little changed from previously. Evaluation of mental status revealed an awake, generally placid or apathetic woman who reacted in a seemingly angry manner to the examiner's attempts to question her. Despite her apparent anger, she could nonetheless be coaxed to cooperate. Digit span was 6 forward. Questions designed to test recent and remote memory led to the following situation: either she refused to answer, or she answered incorrectly. However, when the examiner waited, either silently or with attempts to encourage her, for longer than normal waiting periods (even as long as four to five minutes for a single question) she then gave the correct answer to $70-80 \%$ of the questions. This indicated that her stock of knowledge was not as impaired as one might otherwise have concluded. Rather, she was delayed in reaching into this stock for the correct answer. Tests of language and gestures revealed no aphasia or apraxia. No inattention or primary perceptual problems were seen. Proverb interpretations tended to be concrete. Her ability to find the categorical similarities between similar items was impaired. Her calculating ability was poor.

\section{CASE 4}

G.Z. was a 59 year old, right-handed automobile mechanic admitted to the Neurology Service of the Boston Veterans Administration Hospital on 22 October 1971 for evaluation of dementia. For two years before this admission his family noted progressive mental changes, characterized by memory lapses, sloppy personal habits, occasional outbursts of rage, and paranoid delusions. In addition, he would occasionally stumble while walking; he also had episodic urinary incontinence.

Physical examination on admission was normal. Pertinent findings on the neurological examination are as follows. Mental status: he was awake and alert, but not consistently attentive. He tended to be apathetic, but, on occasion, would suddenly become hostile and even violent. Digit span was 6 forward. Recent memory and remote memory were severely impaired (Wechsler Memory Scale Form I score was 74 on 8 December 1971). Memory, however, was unusual in the following sense: if an excessive and abnormal amount of time was given (with or without statements of encouragement by the examiner to the patient), G.Z. could then improve his performance on both recent and remote memory by approximately $50 \%$. Evaluation of spoken language capabilities revealed no abnormalities. There was no agnosia and no apraxia. Reading comprehension was significantly impaired (he was reading at the 4th grade level, and is a high school graduate). Calculating and abstracting ability were abnormal. Speech was dysphonic, dysarthric, and monotonous.

He had an unblinking, wide-eyed stare with immobile facies. Conjugate vertical gaze in either direction was markedly impaired. Conjugate horizontal gaze was abnormal, but less so than vertical gaze. Only tonic responses were seen to ice-water caloric test of vestibular function. Cranial nerves were otherwise normal. Strength and muscle bulk were normal. Tone was symmetrically increased, with cogwheeling present at the wrists. Deep tendon reflexes were symmetrically increased; bilateral Babinski signs were present, as were bilateral grasp reflexes and snout reflex. Truncal ataxia was present.

Blood, urine, and CSF studies were normal. Radiographs of the skull and chest were negative. Electroencephalography showed an abnormal admixture of theta and delta activity shifting from side to side, perhaps a bit more prominently on the left. Brain scan was negative. Pneumoencephalography revealed generalized atrophy with a $5 \mathrm{~mm}$ shift of the septum pellucidum towards the right. A left carotid angiogram showed a $7 \mathrm{~mm}$ displacement of the pericallosal artery to the right; no mass lesion was seen. 
The diagnosis of progressive supranuclear palsy was made. The patient's subsequent course has been one of progressive deterioration of all the abovementioned neurological signs and symptoms, punctuated by acute pulmonary and urinary tract infections. G.Z. is currently wheelchair bound, unable to care for himself, and nearly mute.

\section{CASE 5}

S.B. is a 64 year old woman referred to the Neurological Referral Center, Boston, for neurological evaluation on 13 January 1971 because of slowness and difficulty of speech. Since 1968, according to both the patient and her husband 'everything has slowed down-first her speech, then her thinking'. This slowing down process has progressed. She was no longer able to organize her household duties, her shopping, her daily affairs. Whereas previously she had managed the family's finances and checking account, she was no longer able to do this. Her personality has altered. She used to be 'eventempered and mild-mannered', and 'interested in life'. Now she has become apathetic with episodic outbursts of irritability. Her husband has difficulty in defining her changes in memory, saying specific-

TABLE

NEUROBEHAVIOURAL FEATURES OF PROGRESSIVE SUPRANUCLEAR PALSY

\begin{tabular}{|c|c|c|c|c|c|c|c|c|c|c|}
\hline Reported by & Case & $\begin{array}{l}\text { Age } \\
\text { at } \\
\text { onset } \\
(y r)\end{array}$ & $\operatorname{Sex}$ & $\begin{array}{l}\text { Initial symptom } \\
\text { or sign }\end{array}$ & $\begin{array}{l}\text { Forget- } \\
\text { ful- } \\
\text { ness }\end{array}$ & $\begin{array}{c}\text { Slow- } \\
\text { ness } \\
\text { of } \\
\text { thought } \\
\text { processes }\end{array}$ & $\begin{array}{l}\text { Person- } \\
\text { ality } \\
\text { change }\end{array}$ & $\begin{array}{l}\text { Impaired } \\
\text { manipula- } \\
\text { tion of } \\
\text { acquired } \\
\text { knowledge }\end{array}$ & $\begin{array}{l}\text { Inappro- } \\
\text { priate } \\
\text { laughing } \\
\text { or } \\
\text { crying }\end{array}$ & Speech \\
\hline Chavany et al. (1951) & 1 & 54 & $\mathbf{M}$ & Dizzy spells & + & 0 & 0 & 0 & 0 & \\
\hline Verhaart (1958) & 1 & 41 & $\mathbf{M}$ & Character changes & 0 & 0 & + & 0 & 0 & Dysarthria \\
\hline Brusa (1961) & 1 & 47 & $\mathbf{F}$ & $\begin{array}{l}\text { Trouble with fine hand } \\
\text { movements }\end{array}$ & - & + & + & $\begin{array}{c}\text { (Slowness of } \\
\text { mental } \\
\text { processes) } \\
\quad ?\end{array}$ & + & Unintelligible \\
\hline \multirow[t]{9}{*}{ Steele et al. (1964) } & 1 & 49 & $\mathbf{M}$ & $\begin{array}{l}\text { Lack of left hand } \\
\text { control }\end{array}$ & 0 & + & + & $\dot{0}$ & - & Dysarthria \\
\hline & 2 & 57 & $\mathbf{M}$ & $\begin{array}{l}\text { Walk unsteady; close } \\
\text { vision impaired }\end{array}$ & + & + & + & 0 & - & Slurred; nasal \\
\hline & 3 & 55 & $\mathbf{M}$ & $\begin{array}{l}\text { Irritable; confused; } \\
\text { unsteady }\end{array}$ & + & + & + & + & - & Dysarthria \\
\hline & 4 & 63 & $\mathbf{M}$ & $\begin{array}{l}\text { Staggering; visual } \\
\text { problems; slurred } \\
\text { speech }\end{array}$ & 0 & + & 0 & 0 & + & $\begin{array}{l}\text { Dysarthria; } \\
\text { explosive }\end{array}$ \\
\hline & 5 & 69 & $\mathbf{M}$ & $\begin{array}{l}\text { Mental deterioration; } \\
\text { visual problems }\end{array}$ & 0 & + & + & 0 & - & $\begin{array}{l}\text { Slow; mono- } \\
\text { tone }\end{array}$ \\
\hline & 6 & 59 & $\mathbf{M}$ & Staggering; irritable & + & + & 0 & 0 & + & Nasal; slurred \\
\hline & 7 & 57 & $\mathbf{M}$ & Tired easily & + & + & + & 0 & - & $\begin{array}{l}\text { Monotone } \\
\text { anarthric }\end{array}$ \\
\hline & 8 & 54 & $\mathbf{M}$ & $\begin{array}{l}\text { Unsteady gait; mild } \\
\text { mental deterioration }\end{array}$ & 0 & 0 & 0 & 0 & - & Dysarthria \\
\hline & 9 & 58 & $\mathbf{M}$ & $\begin{array}{l}\text { Unsteady gait; } \\
\text { personality change }\end{array}$ & 0 & $\mathbf{0}$ & 0 & 0 & - & Slow; slurred \\
\hline Barbeau (1965) & 1 & $45-46$ & $\mathbf{F}$ & 'Premature ageing' & + & + & + & 0 & + & $\begin{array}{r}\text { Slow; lack of } \\
\text { spontaneity }\end{array}$ \\
\hline \multirow[t]{3}{*}{$\begin{array}{l}\text { Messert and Van Nuis } \\
\quad(1966)\end{array}$} & 1 & 64 & $\mathbf{M}$ & $\begin{array}{l}\text { Fracture of } L \text { clavicle } \\
\text { and ischium }\end{array}$ & + & + & + & 0 & + & Dysarthria \\
\hline & 2 & $57-59$ & $\mathbf{M}$ & $\begin{array}{l}\text { Slowing gait; dizziness; } \\
\text { voice change }\end{array}$ & 0 & + & 0 & 0 & 0 & $\begin{array}{l}\text { Monotone; } \\
\text { eventually } \\
\text { almost mute }\end{array}$ \\
\hline & 3 & 61 & $\mathbf{M}$ & Unsteady & + & + & 0 & 0 & + & $\begin{array}{l}\text { Thick and } \\
\text { slurred }\end{array}$ \\
\hline \multirow[t]{7}{*}{$\begin{array}{l}\text { Anastasopoulos et al. } \\
\text { (1967) }\end{array}$} & 1 & 50 & $\mathbf{M}$ & Dysphonia dystonic & 0 & 0 & + & 0 & + & $\begin{array}{l}\text { Unable to } \\
\text { express him- } \\
\text { self }\end{array}$ \\
\hline & 2 & 52 & $\mathbf{M}$ & Unsteady gait & + & 0 & + & 0 & 0 & Dysarthria \\
\hline & 3 & 56 & $\mathbf{M}$ & $\begin{array}{l}\text { Unsteady gait; visual } \\
\text { problems }\end{array}$ & + & 0 & + & 0 & + & Dysarthria \\
\hline & 4 & 63 & $\mathbf{M}$ & Gait problems & + & 0 & 0 & 0 & 0 & $\begin{array}{l}\text { 'Troubles with } \\
\text { language' }\end{array}$ \\
\hline & 5 & 54 & $\mathbf{F}$ & Gait problems & + & 0 & + & $\mathbf{0}$ & 0 & Monotone; low \\
\hline & 6 & 54 & $\mathbf{M}$ & $\begin{array}{l}\text { Gait and memory } \\
\text { problems }\end{array}$ & + & 0 & + & 0 & 0 & Dysarthria \\
\hline & 7 & 58 & $\mathbf{M}$ & $\begin{array}{l}\text { Gait and visual } \\
\text { problems }\end{array}$ & 0 & 0 & 0 & 0 & 0 & \\
\hline
\end{tabular}


TABLE-continued

\begin{tabular}{|c|c|c|c|c|c|c|c|c|c|c|}
\hline Reported by & Case & $\begin{array}{l}\text { Age } \\
\text { at } \\
\text { onset } \\
(y r)\end{array}$ & $\operatorname{Sex}$ & $\begin{array}{l}\text { Initial symptom } \\
\text { or sign }\end{array}$ & $\begin{array}{l}\text { Forget- } \\
\text { ful- } \\
\text { ness }\end{array}$ & $\begin{array}{l}\text { Slow- } \\
\text { ness } \\
\text { of } \\
\text { thought } \\
\text { processes }\end{array}$ & $\begin{array}{l}\text { Person- } \\
\text { ality } \\
\text { change }\end{array}$ & $\begin{array}{l}\text { Impaired } \\
\text { manipula- } \\
\text { tion of } \\
\text { acquired } \\
\text { knowledge }\end{array}$ & $\begin{array}{l}\text { Inappro- } \\
\text { priate } \\
\text { laughing } \\
\text { or } \\
\text { crying }\end{array}$ & Speech \\
\hline Ferri et al. (1968) & 1 & 56 & $\mathbf{M}$ & Disturbance of sight & - & + & + & + & - & Dysarthria \\
\hline Pollingher (1968) & 1 & 55 & $\mathbf{M}$ & $\begin{array}{l}\text { Visual and gait prob- } \\
\text { lems; trouble moving } \\
\text { head }\end{array}$ & 0 & + & 0 & 0 & 0 & Palilalia \\
\hline \multirow[t]{5}{*}{ David et al. (1968) } & 1 & 58 & $\mathbf{F}$ & $\begin{array}{l}\text { Vision and gait prob- } \\
\text { lems }\end{array}$ & 0 & 0 & 0 & 0 & 0 & $\begin{array}{l}\text { Monotone; no } \\
\text { spontaneity }\end{array}$ \\
\hline & 2 & 58 & $\mathbf{M}$ & $\begin{array}{l}\text { Impaired vision and } \\
\text { gait }\end{array}$ & 0 & 0 & 0 & 0 & + & Unintelligible \\
\hline & 3 & 61 & $\mathbf{F}$ & $\begin{array}{l}\text { Impaired vision and } \\
\text { gait }\end{array}$ & + & + & 0 & + & 0 & 0 \\
\hline & 4 & 52 & $\mathbf{M}$ & $\begin{array}{l}\text { Loss of } \mathbf{R} \text { hand } \\
\text { dexterity }\end{array}$ & + & + & 0 & 0 & + & $\begin{array}{l}\text { Palilalia; mono- } \\
\text { tone; explo- } \\
\text { sive }\end{array}$ \\
\hline & 5 & 65 & $\mathbf{F}$ & $\begin{array}{l}\text { Failing vision; rigid } \\
\text { extremities }\end{array}$ & + & 0 & 0 & 0 & 0 & $\begin{array}{l}\text { Palilalia; mono- } \\
\text { tone }\end{array}$ \\
\hline \multirow[t]{4}{*}{ Behrman et al. (1969) } & 1 & 56 & $\mathbf{F}$ & $\begin{array}{l}\text { Falling; lack of } \\
\text { sociability }\end{array}$ & 0 & 0 & + & 0 & 0 & $\begin{array}{l}\text { Dysarthria; } \\
\text { palilalia }\end{array}$ \\
\hline & 2 & 58 & $\mathbf{F}$ & Unsteadiness & + & 0 & 0 & 0 & 0 & $\begin{array}{l}\text { Dysarthria; } \\
\text { slurring }\end{array}$ \\
\hline & 3 & 61 & $\mathrm{~F}$ & Frequent falls & 0 & 0 & 0 & 0 & 0 & Dysarthria \\
\hline & 4 & 56 & $\mathbf{M}$ & Paranoia & + & + & + & 0 & + & Unintelligible \\
\hline $\begin{array}{l}\text { Blumenthal and Miller } \\
\text { (1969) }\end{array}$ & 1 & 60 & $\mathbf{F}$ & Unsteady & 0 & + & 0 & 0 & 0 & Slurred \\
\hline $\begin{array}{l}\text { Constantinidis et al. } \\
\text { (1970) }\end{array}$ & 1 & 52 & $\mathbf{M}$ & $\begin{array}{l}\text { Insomnia; falling; stiff } \\
\text { L leg }\end{array}$ & - & + & 0 & - & - & $\begin{array}{l}\text { Dysarthria; } \\
\text { monotone }\end{array}$ \\
\hline \multirow[t]{3}{*}{ Newman et al. (1970) } & 1 & 64 & M & Stiffness; forgetfulness & + & 0 & 0 & 0 & 0 & 0 \\
\hline & 2 & 52 & $\mathbf{M}$ & $\begin{array}{l}\text { Falling; indistinct } \\
\text { speech }\end{array}$ & 0 & 0 & 0 & 0 & 0 & Indistinct \\
\hline & 3 & 63 & $\mathrm{~F}$ & $\begin{array}{l}\text { Dizziness; weakness; } \\
\text { speech problems }\end{array}$ & 0 & 0 & 0 & 0 & 0 & 0 \\
\hline Scott (1970) & 1 & & $\mathbf{M}$ & Falling to $\mathbf{R}$ & + & + & 0 & 0 & + & 0 \\
\hline Steele (1970) & 1 & 54 & $\mathbf{M}$ & $\begin{array}{l}\text { Swallowing difficulty; } \\
\text { speech problems }\end{array}$ & + & 0 & 0 & 0 & 0 & $\begin{array}{l}\text { Indistinct; } \\
\text { abbreviated }\end{array}$ \\
\hline \multirow[t]{5}{*}{ Albert et al. (1973) } & 1 & 60 & $\mathbf{M}$ & $\begin{array}{l}\text { Stammering; gait } \\
\text { problems }\end{array}$ & + & + & + & + & + & Dysarthria \\
\hline & 2 & 74 & $\mathbf{M}$ & Vertigo; headaches & + & + & + & + & 0 & 0 \\
\hline & 3 & 57 & $\mathbf{F}$ & $\begin{array}{l}\text { Slurred speech; gait } \\
\text { problems }\end{array}$ & + & + & + & + & 0 & Nasal; slow \\
\hline & 4 & 57 & $\mathbf{M}$ & Personality changes & + & + & + & + & + & Dysarthria \\
\hline & 5 & 64 & $\mathbf{F}$ & Slow, slurred speech & + & + & + & + & - & $\begin{array}{l}\text { Barylalic, hypo- } \\
\text { phonic, slow }\end{array}$ \\
\hline
\end{tabular}

Key: + mention of change in literature, - mention of no change, 0 no mention.

ally 'she is getting a little forgetful, but she has a good memory'.

When initially seen in January 1971, she had a minimal decrease in facial expression and spoke with a hypophonic voice. Her proverb interpretation tended to be concrete or incomplete. Her mental arithmetic was impaired. When writing she had a tendency toward micrographia. The remainder of the examination of mental status was normal.

There was a trace of sialorrhoea with pooling of saliva in the posterior pharynx. Cranial nerves were normal. There was cogwheel rigidity in both arms which increased with concomitant exercise of the opposite arm. Muscle bulk and strength were normal, but there was a decrease in speed of movement. The reflexes were hyperactive on the right compared with the left. Plantar responses were flexor on the left and equivocal on the right. Sensation and coordination were normal. It was felt that an extrapyramidal syndrome was present and treatment with amantadine was instituted.

She was followed up at regular intervals during the next 18 months. In March 1971 L-dopa therapy was started. All signs and symptoms slowly progressed.

In June 1972 the following additional features were noted. There was mild rigidity of her neck muscles on passive motion. Her handwriting was slower and smaller than on previous examinations, but no tremor was present. There was marked limitation of upward and downward gaze, with slow eye movements, and slight limitation on lateral gaze. 
The diagnosis of progressive supranuclear palsy was made.

Detailed clinical evaluation of mental status was carried out in September 1972. Her speech was slow and thick, mildly barylalic, but still clearly understandable. She was alert, attentive, and socially appropriate.

Immediate recall of digits was seven forward and five backwards. Recent memory was deficient in an unusual way: her first answer to almost every question was 'I don't know'. However, if the examiner encouraged her by saying 'Sure, you know; just take your time', she would correctly respond to $95 \%$ of the questions. The latency between question and response was often inordinately long -in some cases as long as $4 \frac{1}{2}$ minutes (often taxing the patience of the examiner). Remote memory was intact.

Language functions were as follows. Spontaneous speech has been described. No paraphasias were heard. Naming was excellent on confrontation for high and very low frequency words. Although she complained of having difficulty with words, she had no naming defect. She did, however, have a timerelated word-finding defect: in one minute she was able to find only three words beginning with the letter B. At five minutes she had listed 12 ; at 10 minutes 23 ; at 15 minutes 33 . Tests of repetition, comprehension of spoken and written language, and reading aloud were normal, except for the slow reading rate.

For simple mental calculations her responses were quick and accurate. With more complex arithmetic problems, she was slow but correct. Her proverb interpretations were concrete and she had difficulty finding similarities in two similar objects.

\section{REVIEW OF LITERATURE}

A summary of the mental signs and symptoms of progressive supranuclear palsy is presented in the Table.

Many of the cases of progressive supranuclear palsy reported in the neurological literature do not characterize the dementia. Forty-two cases provided sufficient data for analysis of mental signs and symptoms. The following key features stand out. Twenty-seven cases cited 'forgetfulness' as a chief characteristic. It should be stressed that this forgetfulness may not necessarily be a true memory defect. We have observed with our five patients a situation in which the patients do not or cannot respond at first to simple questions designed to test recent and remote memory. However, if we give these patients an abnormal amount of time in which to respond, and if we encourage the subject during this time (for example, 'Come on; maybe you do remember; just give it a try; take your time'), he पo often produces the correct answer. Thus, memory as such may not be truly impaired. What seems to be impaired in many cases, rather, is a timing mechanism which allows the memory system of $\overrightarrow{\vec{B}}$ normal people to function at the correct speed. The husband of one of our patients stated 'she is getting a little forgetful, but she has a good memory'.

Twenty-six cases reported 'slowness of thought processes' or other similar phrases. Tasks requiring verbal manipulation or perceptual-motor skills would be performed incorrectly only if the examiner used as a criterion the 'normal amount of time' ordinarily used to perform the task. As was seen for memory, tasks requiring verbal or perceptual-motor agility could be performed adequately if the subjects were given more thanp the normal amount of time. One of our patient remarked, 'You're coming at me too fast, I nee more time to put things together.'

Twenty-four cases in the literature described $\mathscr{Q}$ 'personality or mood change'. These changes seemed to fall into two major categories. One category grouped the reactions of indifference apathy, or depression; this group was by far the larger. The other category included progressive irritability and/or euphoria. Inappropriate, 'forced' laughing or crying appeared intermittently in 14 cases. Brief outbursts of rage behaviour, even in the patients who were generally apathetic or depressed, were not infrequently reported.

Finally, a small number of patients (nine cases) were reported as having impairments of calculating ability or ability to deal with abstract material-functions which could properly be placed in the general category of impaired ability to manipulate acquired knowledge.

Strikingly, little mention is made in any of the case reports of those defects considered to be in the category of the 'higher cortical functions'. There are no instances of aphasia, agnosia, or apraxia described. The verbally-mediated activities and perceptual-motor skills appear rela- م tively well preserved, although slowed down in $N$ keeping with the general bradykinetic state of these patients. 


\section{DISCUSSION}

DEMENTIA OF PROGRESSIVE SUPRANUCLEAR PALSY A composite clinical profile can be developed, characterizing the dementia of progressive supranuclear palsy. The patient is often a male in his early $50 \mathrm{~s}$. He may have (1) forgetfulness, (2) slowness of thought processes, (3) alterations of personality with apathy or depression; occasionally with irritability or euphoria, with inappropriate laughing or crying, and with brief outbursts of rage, (4) impaired ability to manipulate acquired knowledge-for example, poor calculating and abstracting ability. Underlying these clinical abnormalities seems to be an excessive time delay in the carrying out of intellectual functions. Verbal and perceptualmotor capacities may be strikingly preserved if the patient is given sufficient time to respond.

Progressive supranuclear palsy is a disease with a known subcortical pathology involving, in particular, the pallidum, red nucleus, subthalamic nuclei, midbrain reticular formation, substantia nigra, locus coeruleus, superior colliculi, vestibular and dentate nuclei. In these regions nerve cell loss, gliosis, neurofibrillary tangles, and granulovacuolar changes have been noted (Steele et al., 1964). Because progressive supranuclear palsy seems to have a characteristic pattern of dementia coupled with a subcortical pathology, we analysed the mental aspects of other subcortical neurological diseases to see if a similar relationship obtained.

SUBCORTICAL DEMENTIA Descriptions of dementia after subcortical lesions are neither new nor rare. In 1938 Smyth and Stern published a clinicopathological study of tumours of the thalamus. Symptoms of mental impairment such as 'inattention, disorientation, confusion, and emotional disturbances' dominated the clinical picture. One could remark that these tumours may have produced secondary effects on the cortex and that the symptoms were really cortical in origin; however, in the next year Stern (1939) described a dementing syndrome associated with bilateral symmetrical degeneration of the thalamus. This patient's symptoms were 'lack of memory and orientation, a tendency to perseveration, and changes in personality such as inertia and complete lack of initiative'.
Even before Stern, case reports appear in the literature describing dementia in the presence of non-cortical brain pathology-for example, olivopontocerebellar degeneration (van Bogaert and Bertrand, 1929; van Bogaert, 1946); progressive pallidal degeneration (Winkelman, 1932). The specific symptoms listed for these dementing syndromes include 'disinterest; then, a slowing down of intellectual activity; next, a rapidly developing confusion, and incoherent agitation'. Williams and Pennybacker (1954), in a study of 180 patients with verified intracranial lesions, conclude that 'memory impairment is most common and specific when the area surrounding the floor and walls of the third ventricle is disturbed'. In a study on the natural history of Parkinson's disease, Pollock and Hornabrook (1966) report a $20 \%$ overall incidence of dementia. In describing the dementia of Parkinson's disease they refer to Mjones (1966) who reported 'an impairment of their intellectual functions in the wider sense with immediate memory and thought processes particularly impaired'.

The recent monograph on the WernickeKorsakoff syndrome by Victor et al. (1971) has clear descriptions of mental disturbance. In the chronic stage of the illness, the patients were apathetic but subject to short outbursts of irritability or anger. Memory was impaired; but 'vocabulary and general facility with language' were well preserved. No apraxia, agnosia, agraphia, or constructional defects were observed. The memory defects were correlated with lesions of the dorsomedial nucleus of the thalamus, the medial pulvinar, and the mamillary bodies. The apathetic state was attributed to a functional derangement in the thalamus.

We have seen that bradykinesis, manifesting itself in aspects of intellectual as well as motor functioning, may be associated with subcortical dementia. An extreme form of this bradykinesis may be seen in akinetic mutism. This syndrome, as has been shown by Segarra (1970), may occasionally result from a small, midline, butterfly-shaped lesion at the thalamomesencephalic junction. He suggests that in these cases the severe behavioural disturbance of akinetic mutism may result from a disconnection or deafferentation of thalamic nuclei from ascending midline mesencephalic reticular impulses.

In recent years a growing awareness of the 
functional interdependence of cortical and subcortical structures has developed (Bell, 1968). Arousal, the ability to maintain a state of wakefulness, and the smooth timing of motor activity are some of the elements necessary for normal behaviour which are dependent on thalamic and reticular activating nuclei and connections (Jasper et al., 1958; Purpura and Yahr, 1966). Riklan (1972), in his studies of levodopa and the subcortical control of human behaviour, emphasizes the role of 'behavioural activation' on patient performance. Such 'behavioural activation' can be induced by electrical stimulation of the thalamus and reticular activating system (Lindsley, 1958).

If neuropharmacological and electrical techniques of subcortical stimulation can 'activate', it would not be surprising that lesions in these same structures might 'de-activate'. We might speculate that disorders of timing and activation, resulting from lesions in thalamic and subthalamic nuclei, the reticular activating system, and their connections, could be at the basis of the pattern of dementia we have observed in patients with progressive supranuclear palsy.

From these various studies, a consistent pattern emerges-a pattern of dementia characteristic of various neurological syndromes which all have a subcortical pathology. These subcortical dementias are characterized by (1) some form of memory defect, (2) a general slowing down of intellectual activity, (3) alterations of personality-typically, inertia or apathy; occasionally with episodic irritability, (4) impaired ability to manipulate acquired knowledge. This typical pattern of dementia associated with varying subcortical syndromes is the same as that associated with progressive supranuclear palsy.

CORTICAL DEMENTIA The cortical dementias result from a group of different diseases which produce the signs and symptoms of dementia because of cerebral cortical lesions or dysfunction. The signs and symptoms can be grouped into two major categories: (1) languagedependent activities, (2) perceptual or perceptualmotor skills. Ordinarily, more than one type of disturbance is present for each category. The review by Hécaen (1969) details the defects which, in general, include the aphasias, apraxias, and

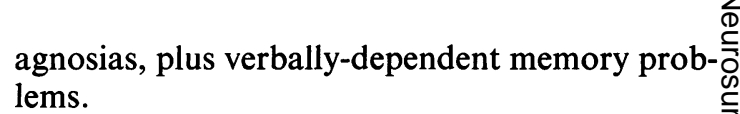

A special theoretical problem arises from con- $\stackrel{0}{-0}$ sideration of the intellectual impairment afteres frontal lobe disease that does not affect the $=$ language areas. Disturbances of frontal lobe activity result in a clinical picture which is re-? markably similar to that of the subcortical $\overrightarrow{\bar{\omega}}$ dementias. The extensive review by Benson ando Geschwind (1972) of disorders of mental status associated with frontal lobe pathology reports on $\frac{\bar{p}}{\mathrm{p}}$ frontal head injury, psychosurgery, and frontal ${ }_{\triangle}^{\Phi}$ brain tumours, plus several other neurological@ disorders primarily affecting the frontal lobes. As with the subcortical dementias, the signs and symptoms most frequently cited are emotional $\omega$ and personality changes, forgetfulness or memory disturbances, and loss of 'abstracting ability'. We may add to these observations the iy descriptions of pseudobulbar palsy resulting iv from bilateral frontal lobe pathology (Benso: $\overrightarrow{0}$ and Geschwind, 1972). A disturbance in the control of behaviour-a lability of emotion 1 is expression with forced laughing or crying-is $\frac{7}{2} \vec{T}$ characteristic finding; again, this is a common $\mathbb{8}$ feature of the subcortical dementias.

The explanation for the similarity of clinicat characteristics between the frontal lobe sy前 $\vec{\theta}$ dromes and the subcortical dementias can only be speculative. Nauta (1971) indicates that the frontal lobe disorders are characterized primarily by a disturbance of behavioural programming. He adds that patients with frontal lobe pathology are unable to maintain their $\stackrel{\circ}{\circ}$ behaviour with a normal 'stability-in-time'. $\overrightarrow{\vec{D}}$ Luria and Homskaya (1964) stress the dissocia- 3 tion of verbal signals from the subjects' actions in frontal lobe diseases. We have already pointed out that in the subcortical dementias, while verbal processing seems intact, there is an abnormal time delay in associating verbal input with response.

It is not surprising that frontal syndromes and the subcortical dementias should be similar, 0 given their anatomical connections. According to Nauta (1971) 'the unique feature of the neural circuitry [of the frontal lobes] is [in part] the reciprocal relationship of the frontal cortex . with the telencephalic limbic system and its sub- $N$ cortical correspondents, in particular the hypo- $\mathcal{\omega}$ thalamus and meso- and diencephalic structures 
associated with the hypothalamus ... It would seem justified to view the frontal cortex as the major neocortical representative of the limbic system.'

\section{CONCLUSIONS}

A characteristic pattern of dementia, 'subcortical dementia', may be contrasted sharply with that of the cortical dementias. Although the specific subcortical structures involved may differ, the fact that lesions in these areas produce a common symptomatology suggests that a common pathophysiological mechanism may be present. We propose as a tentative hypothesis that the common mechanisms underlying the subcortical dementias are those of impaired timing and activation. Impaired function of the reticular activating systems or a disconnection of reticular activating systems from thalamic and subthalamic nuclei may result in a slowing down of normal intellectual processes. Cortical systems responsible for perceiving, storing, and manipulating knowledge may be intact. They may, however, be abnormally activated; and once activated, they may take an excessive amount of time to carry out intellectual processing. In ordinary human relationships, a 'normal' range of time is allowed for communication. If no response is forthcoming within this 'normal' range of time, one moves on to the next topic, assuming that someone 'doesn't know' or 'doesn't remember', or 'doesn't care'. In a clinical diagnosis if someone is shown to not know or not remember or not care for a long enough time, he will surely be called demented.

This hypothesis has immediate therapeutic implications. If the subcortical dementias are produced by disturbances of activating, alerting, or timing mechanisms, then drugs which have an effect on the anatomical systems dealing with these mechanisms (Riklan and Levita, 1969)-for example, amphetamines, L-dopa, phenothiazines, etc.-may have a therapeutic usefulness in the treatment of dementia.

We wish to thank Dr. Norman Geschwind and Dr. D. Frank Benson for their advice on the manuscript.

\section{REFERENCES}

Alajouanine, T., Delafontaine, P., and Lacan, J. (1926). Fixité du regard par hypertonie, prédominant dans le sens vertical, avec conservation des mouvements automaticoréflexes, aspect spécial de syndrome de Parinaud par hypertonie associée à un syndrome extrapyramidal avec troubles pseudo-bulbaires. Revue Neurologique, 33, 410 418.

Anastasopoulos, G., Routsonis, C., and Constas, C. G. (1967). Dystonie oculo-facio-cervicale (progressive supranuclear palsy). Revue Neurologique, 116, 85-88.

Barbeau, A. (1965). Dégénérescence plurisystématisée du névraxe. Union Médicale du Canada, 94, 715-718.

Behrman, S., Carroll, J. D., Janota, I., and Matthews, W. B. (1969). Progressive supranuclear palsy. Clinico-pathological study of four cases. Brain, 92, 663-678.

Bell, D. S. (1968). Speech functions of the thalamus inferred from the effects of thalamotomy. Brain, 91, 619-638.

Benson, D. F., and Geschwind, N. (1972). Psychiatric conditions associated with focal lesions of the central nervous system. In American Handbook of Psychiatry. Edited by M. F. Reiser. Basic Books: New York. (In press.)

Blumenthal, H., and Miller, C. (1969). Motor nuclear involvement in progressive supranuclear palsy. Archives of Neurology (Chicago), 20, 362-367.

Bogaert, L. van (1946). Aspects cliniques et pathologiques des atrophies pallidales et pallido-luysiennes progressives. Journal of Neurology, Neurosurgery, and Psychiatry, 9, 125157.

Bogaert, L. van, and Bertrand, I. (1929). Une variété d'atrophie olivo-pontine à évolution subaiguë avec troubles démentiels. Revue Neurologique, 36, ler Semestre, 165-178.

Brusa, A. (1961). Dégénérescence plurisystématisée du névraxe, de caractère sporadique, à début tardif et évolution subaiguë. Revue Neurologique, 104, 412-429.

Chavany, J. A., Bogaert, L. van, and Godlewski, S. T. (1951). Sur un syndrome de rigidité à prédominance axiale, avec perturbation des automatismes oculo-palbébraux d'origine encéphalitique. Presse Medicale, 59, 958-962.

Constantinidis, J., Tissot, R., and Ajuriaguerra, J. de (1970). Dystonie oculo-facio-cervicale ou paralysie progressive supranucléaire de Steele-Richardson-Olszewski. Revue Neurologique, 122, 249-262.

Cornil, L., and Kissel, P. (1929). Syndrome extrapyramidal avec paralysie verticale du regard et conservation des mouvements automatico-réflexes. Remarques sur les synergies oculo-palpébrales du syndrome de Parinaud. Revue Neurologique, 36, 1189-1191.

David, N. J., Mackey, E. A., and Smith, J. L. (1968). Further observations in progressive supranuclear palsy. Neurology (Minneap.), 18, 349-356.

Ferri, E., Parma, M., Passeri, S., and Zampollo, A. (1968). Ia sindrome di Steele, Richardson e Olszewski (o "progressive supranuclear palsy'). Minerva Medica, 59, 5831-5838.

Hécaen, H. (1969). Aphasic, apraxic and agnosic syndromes in right and left hemisphere lesions. In Handbook of Clinical Neurology, vol. 4, pp. 291-311. Edited by P. J. Vinken and G. W. Bruyn. North-Holland: Amsterdam.

Jasper, H. H., Proctor, L. D., Knighton, R. S., Noshay, W. C., and Costello, R. T. (eds.) (1958). Reticular Formation of the Brain. Little, Brown: Boston.

Lindsley, D. B. (1958). The reticular system and perceptual discrimination. In Reticular Formation of the Brain, pp. 513-534. Edited by H. H. Jasper, L. D. Proctor, R. S. Knighton, W. C. Noshay, and R. T. Costello. Little, Brown: Boston.

Luria, A. R., and Homskaya, E. D. (1964). Disturbance in the regulative role of speech with frontal lobe lesions. In The Frontal Granular Cortex and Behavior, pp. 353-371. Edited by J. M. Warren and K. Akert. McGraw-Hill: New York. 
Messert, B., and Nuis, C. van (1966). A syndrome of paralysis of downward gaze, dysarthria, pseudobulbar palsy, axial rigidity of neck and trunk and dementia. Journal of Nervous and Mental Disease, 143, 47-54.

Mjönes, H. (1949). Paralysis agitans; clinical and genetic study. Acta Psychiatrica Neurologica, Suppl. 54. (Cited in M. Pollock and R. W. Hornabrook.)

Nauta, W. J. H. (1971). The problem of the frontal lobe: a reinterpretation. Journal of Psychiatric Research, 8, 167187.

Newman, N., Gay, A. J., Stroud, M. H., and Brooks, J. (1970). Defective rapid eye movements in progressive supranuclear palsy. Brain, 93, 775-784.

Pollingher, B. (1968). Sindromul Steele-RichardsonOlszewski. Neurologia, Psihiatria, si Neurochirurgia (Bucur), 13, 413-418.

Pollock, M., and Hornabrook, R. W. (1966). The prevalence, natural history and dementia of Parkinson's disease. Brain, 89, 429-448.

Powell, D. (1970). Progressive supranuclear palsy. Journal of the Irish Medical Association, 63, 189-190.

Purpura, D. P., and Yahr, M. D. (1966). The Thalamus. Columbia University Press: New York.

Riklan, M., and Levita, E. (1969). Subcortical Correlates of Human Behavior. Williams and Wilkins: Baltimore.

Riklan, M. (1972). Levodopa and behavior. Neurology (Minneap.), 22, no. 5, part 2, 43-55.
Scott, D. (1970). Progressive supranuclear palsy in a Navajo. Rocky Mountain Medical Journal, 67, 35-37.

Segarra, J. M. (1970). Cerebral vascular disease and behavior. 1. Archives of Neurology (Chicago), 22, 408-418.

Smyth, G. E., and Stern, K. (1938). Tumours of the thalamus -a clinico-pathological study. Brain, 61, 339-374.

Steele, J. C., Richardson, J. C., and Olszewski, J. (1964). Progressive supranuclear palsy. Archives of Neurology (Chicago), 10, 333-359.

Steele, J. C. (1970). Progressive supranuclear palsy. Report of

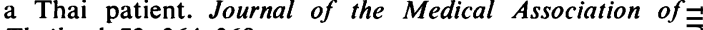
Thailand, 53, 364-368.

Stern, K. (1939). Severe dementia associated with bilaterato symmetrical degeneration of the thalamus. Brain, 62, 157171.

Verhaart, W. J. C. (1958). Degeneration of the brain stem reticular formation, other parts of the brain stem and the $\mathbb{\Phi}$ cerebellum. An example of heterogenous systemic degeneration of the central nervous system. Journal of $\infty$ Neuropathology and Experimental Neurology, 17, 382-391. Victor, M., Adams, R. D., and Collins, G. H. (1971). The Wernicke-Korsakoff Syndrome. Davis: Philadelphia.

Williams, M., and Pennybacker, J. (1954). Memory disturb- $\omega$ ances in third ventricle tumours. Journal of Neurology, Neurosurgery, and Psychiatry, 17, 115-123.

Winkelman, N. W. (1932). Progressive pallidal degeneration:? a new clinicopathologic syndrome. Archives of Neurology and Psychiatry (Chicago), 27, 1-21. 